\title{
In DRG11 Knock-Out Mice, Trigeminal Cell Death Is Extensive and Does Not Account for Failed Brainstem Patterning
}

\author{
Mark F. Jacquin, ${ }^{1}$ Joop J. A. Arends, ${ }^{1}$ Chuanxi Xiang, ${ }^{2,3,4}$ Lee A. Shapiro, ${ }^{5}$ Charles E. Ribak, ${ }^{5}$ and Zhou-Feng Chen ${ }^{2,3,4}$ \\ Departments of ${ }^{1}$ Neurology, ${ }^{2}$ Anesthesiology, ${ }^{3}$ Psychiatry, and ${ }^{4}$ Developmental Biology, Washington University School of Medicine, St. Louis, Missouri \\ 63110, and 5Department of Anatomy and Neurobiology, School of Medicine, University of California at Irvine, Irvine, California 92697
}

\begin{abstract}
A previous study (Ding et al., 2003) showed that the homeodomain transcription factor DRG11 is necessary for pattern formation in the trigeminal nucleus principalis $(\mathrm{PrV})$, the requisite brainstem nucleus for development of the whisker-to-barrel cortex pathway. However, it is not known how DRG11 contributes to pattern formation. Anatomical studies were performed in DRG11 knock-out $(-/-)$ and DRG11/Bax double $-/-$ mice to test the hypotheses that DRG11 is required for neuronal survival in the V pathway and that PrV cell death is sufficient to explain pattern alterations. At birth, $D R G 11^{-/-}$mice had equivalent cell loss in the $\mathrm{V}$ ganglion, $\operatorname{PrV}$, and spinal V subnucleus interpolaris (SpVi). Because whisker-related patterns were normal in the $\mathrm{SpVi}$, cell death would not appear to explain failed pattern formation in the mutant PrV. Electron microscopy revealed exuberant apoptosis and necrosis as the mechanisms of PrV cell death occurring in the late prenatal and newborn $D R G 11^{-1-}$, when such cell death was up to six times more prevalent than normal. $D R G 11$ heterozygote and $\mathrm{Bax}^{-/-}$mice were crossed in an attempt to dissociate $\operatorname{PrV}$ patterning anomalies from exuberant apoptosis in $D R G 11^{-/-}$mice. Both DRG11 ${ }^{-/-}$and DRG11/Bax double -/- mutants lacked whisker-related patterning in their PrV, despite $\mathrm{Bax}^{-/-}$-induced rescue of $\mathrm{V}$ ganglion and $\mathrm{PrV}$ cells. Thus, apoptotic cell death is not a sufficient cause of failed pattern formation in the $\operatorname{PrV}$ of the $D R G 11^{-/-}$. A signaling pathway involving DRG11 may, therefore, be the elusive PrV pattern maker.
\end{abstract}

Key words: transcription factors; Bax; barrels; whiskers; principalis; interpolaris

\section{Introduction}

Prominent barrel-like somatotopic patterns exist in the primary afferent axons and intrinsic neurons of the trigeminal $(\mathrm{V})$ brainstem nucleus principalis $(\mathrm{PrV})$ and spinal $\mathrm{V}$ subnuclei interpolaris (SpVi) and caudalis (Henderson and Jacquin, 1995). PrVbased inputs pattern the ventroposteromedial thalamus (Killackey and Fleming, 1985), which, in turn, patterns the layer IV cells of the S1 (primary somatosensory) cortex (Woolsey and Van der Loos, 1970; Killackey et al., 1990). Transgenic preparations have allowed tests of the necessity and sufficiency of many genes in barrel pattern formation (Erzurumlu et al., 2006). The following are necessary: the NMDA NR1 receptor (Iwasato et al., 2000) and associated intracellular signaling molecules including adenylyl cyclase type 1 (Welker et al., 1996), phospholipase C- $\beta$ (Hannan et al., 2001), protein kinase A (Inan et al., 2006; Watson et al., 2006), RIM1- $\alpha$ (Lu et al., 2006), synaptic Ras GTPase (Barnett et al., 2006), GAP-43 (Maier et al., 1999), and the transcription factors DRG11 (Ding et al., 2003) and Hoxa2 (Oury et al.,

Received Sept. 13, 2007; revised Feb. 12, 2008; accepted Feb. 25, 2008.

This work was supported by National Institutes of Health Grants R01-NS046036 and P01-NS049048 (M.F.J., Z.-F.C.) and R01-NS38331 (C.E.R.). We thank Zhiyin Shan for expert technical assistance, Dr. Michael Howard for statistical assistance, Dr. Reha Erzurumlu for providing mice, and Dr. Thomas Woolsey for novel ideas.

Correspondence should be addressed to Dr. Mark F. Jacquin, Department of Neurology, Box 8111, Washington University School of Medicine, St. Louis, M0 63110. E-mail: jacquinm@neuro.wustl.edu.

DOI:10.1523/JNEUROSCI.4203-07.2008

Copyright $\odot 2008$ Society for Neuroscience $\quad$ 0270-6474/08/283577-09\$15.00/0
2006). Conversely, the secreted signaling molecule FGF8 is cortically sufficient for barrel formation because the ectopic introduction of FGF8 duplicates the barrel field (Fukucki-Shimogori and Grove, 2001). Many other molecules are neither necessary nor sufficient but rather modulate barrel-like development, such as nerve growth factor (Henderson et al., 1994), serotonin (Bennett-Clarke et al., 1994; Cases et al., 1996), trkB (Lush et al., 2005), and ephrin-associated molecules (Vanderhaeghen et al., 2000). Almost all of these genes/molecules function in barrel cortex development. Only NMDA NR1 (Li et al., 1994; Iwasato et al., 1997), DRG11, and Hoxa2 are necessary for barrel-like patterning in the PrV. Insofar as PrV is the $\mathrm{V}$ nucleus that is required for thalamic and cortical patterning (Killackey and Fleming, 1985) and because $\operatorname{PrV}$ is the first nucleus in the pathway to develop barrel-like patterns (Bates and Killackey, 1985; Chiaia et al., 1992), PrV may be the true pattern maker in this system.

$D R G 11$ is the first transcription factor shown to be necessary for barrel-like development (Ding et al., 2003), functioning selectively in the PrV, with no patterning function in the spinal V nucleus. The present study addresses how DRG11 impacts $\operatorname{PrV}$ patterning. We tested the hypotheses that $D R G 11$ is required for neuronal survival in the $\mathrm{V}$ pathway and that, in $D R G 11^{-/-}$mice, excessive $\operatorname{PrV}$ cell death is sufficient to explain $\operatorname{PrV}$ pattern alter-

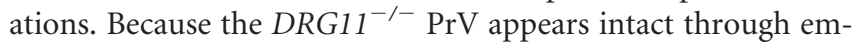
bryonic day 16 (E16), when excess dying cells were first noted and the $\operatorname{PrV}$ first appears diminutive, $\operatorname{PrV}$ neuronal apoptosis may be 
the primary consequence of the mutation. Our objectives were to as follows: (1) reveal how, to what extent, and when PrV cells die in $D R G 11^{-1-}$ mice, (2) assess whether the cell death phenotype is specific to the PrV or whether it also occurs in the spinal V nucleus and $\mathrm{V}$ ganglion, and (3) test whether PrV patterning anomalies can be dissociated from exuberant apoptotic cell death by crossing DRG11 $1^{+/-}$and Bax ${ }^{-/-}$mice in which normal patterning would indicate that DRG11 is necessary for PrV cell survival, not patterning.

\section{Materials and Methods}

Generation, maintenance, and genotyping of mutant mice. DRG11 mice were generated by breeding mice heterozygous for a null mutation in the DRG11 gene, as described previously (Chen et al., 2001). Bax mice were generated by breeding mice heterozygous for a null mutation in the Bax gene (Jackson B6.129X1-Bax $x^{\text {tm1Sjk } / J) . ~ B a x / D R G 11 ~ d o u b l e ~}$ $-/-$ mice were generated by breeding homozygous $B a x^{-/-}$females with heterozygous DRG11 males. In all cases, the presence of a vaginal plug was deemed embryonic day 0.5 . All cases were genotyped by a standard PCR-based method by the use of DNA extracted from tail clips taken before they were killed, as described previously (Chen et al., 2001). Mice were maintained according to approved protocols in the mouse facility of the Division of Comparative Medicine at the Washington University School of Medicine.

Light microscopy. Save for one group of $\mathrm{Bax}^{-1-}$ embryos and an agematched wild-type control group that were killed on E17 (prompted by unexpectedly normal cell numbers obtained in newborn Bax mutants) and immersion fixed, all cases contributing light microscopic data to this report were taken on the day of birth, postnatal day 0 (P0). The latter cases were anesthetized by hypothermia and perfused through the heart with saline, followed by $4 \%$ paraformaldehyde in phosphate buffer $(0.1$ $\mathrm{M}, \mathrm{pH}$ 7.4) or, for cases intended for electron microscopy, $2 \%$ paraformaldehyde and $2 \%$ glutaraldehyde. Heads were postfixed at $4{ }^{\circ} \mathrm{C}$ for variable periods ranging from overnight to several months. Brains were removed, and the tissue at the base of the skull containing the $\mathrm{V}$ ganglion was decalcified in 5\% trichloroacetic acid for $1-2 \mathrm{~d}$ at $4^{\circ} \mathrm{C}$, embedded in gelatin, and sectioned horizontally at $40 \mu \mathrm{m}$ on a sliding microtome. Gelatin embedded brains were cut transversely at $60 \mu \mathrm{m}$. This tissue thickness difference compensated for differential shrinkage of the ganglia and brainstems on slides. Serial sections were plated on chrome-alum subbed slides, Nissl stained with cresyl violet (Sigma, St. Louis, MO), dehydrated in graded alcohols, and cleared in xylenes, and coverslips were applied with DPX (BDH, Poole, UK).

In some of the DRG11/Bax double knock-outs, brainstem sections were taken as above but instead were processed for cytochrome oxidase staining to reveal the presence or absence of whisker-related patterning in the PrV and SpV (Henderson et al., 1994). Sections were incubated in phosphate buffer containing $0.24 \mathrm{mg} / \mathrm{ml}$ cytochrome $c$ (Sigma), 0.5 $\mathrm{mg} / \mathrm{ml}$ diaminobenzidine (Sigma), and $44 \mathrm{mg} / \mathrm{ml}$ sucrose (Sigma) for $2-4 \mathrm{~h}$ at $37^{\circ} \mathrm{C}$ under gentle agitation or until whisker-related patchiness was visible in the stained sections. Sections were mounted onto gelatincoated glass slides and observed under an Olympus (Tokyo, Japan) microscope (BX51).

Electron microscopy. To determine the mechanism of PrV cell death in the $D R G 11^{-/-}$, as well as the prevalence and time course of PrV cell death, six cases were processed on the day of birth for ultrastructural analyses (four $D R G 11^{-/-}$, two wild-type), along with four DRG11 and four wild-type littermate embryos from each of days E14, E16, and E18. Aldehyde perfusion-fixed tissues were processed according to the methods of Golden et al. (1997). Tissue processing and stereological analyses (see below) were performed blind to genotype, which was assessed at a later date, as above. Brainstems were cut into $50 \mu \mathrm{m}$ sections on a vibratome, and regions containing the $\operatorname{PrV}$ were extracted under a dissecting microscope. They were embedded according to established protocols (Shapiro and Ribak, 2006), and semithin sections were cut from a minimum of two separate blocks per case. Semithin sections were mounted onto glass slides and counterstained with toluidine blue, and coverslips were applied. The PrV was identified in these sections, and the embedded blocks were trimmed so that $70 \mathrm{~nm}$ ultrathin sections could be cut and mounted onto mesh grids (100 $\mu \mathrm{m}^{2} /$ grid square; Ted Pella, Redding, CA).

Data analysis. For all estimates of total cell number in the $\mathrm{V}$ ganglia or $\mathrm{PrV}$, the optical disector probe was used, as implemented by the Stereo Investigator software package (MicroBrightField, Williston, VT). This procedure was performed at a final screen magnification of $3330 \times$. In the $\mathrm{V}$ ganglia and $\mathrm{PrV}$, every other section was sampled throughout the entire structure. Because of the inherent difficulty of delineating rostral and caudal borders of the SpVi in Nissl-stained material, only a single section through the SpVi at the level of the obex was counted. (The SpV counts, therefore, are not a stereological estimate.) Pilot studies determined the variables of Stereo Investigator, including the size of the counting brick and sampling grid, to yield results with a coefficient of error $(m=0)$ (Gunderson, 1987) for the population estimate of 0.14 or less (mean of $0.08 \pm 0.02$ ). In the PrV, all cells larger than $2 \mu \mathrm{m}$ in diameter were counted; in the $\mathrm{V}$ ganglion, in which numerous spindle shaped non-neuronal cell types are readily identified and excluded from the count, the size cutoff was $3 \mu \mathrm{m}$. Sample sizes are listed on Figure 3.

To ascertain the sizes of $\mathrm{V}$ ganglion cells on the day of birth in the varied genotypes, which suggests particular cell categories differentially affected by mutations (Rebelo et al., 2006), ganglion cell volume estimates were performed. The optical rotator probe of Stereo Investigator was used at a final screen magnification of $3330 \times$, in conjunction with the systematic uniform random sampling procedure provided by the optical disector probe. A minimum of 409 somata were assessed per genotype derived from the following sample sizes: five wild type, five DRG $11^{-/-}$, four Bax/DRG11 double ${ }^{-/-}$, and three Bax ${ }^{-/-}$

To ascertain the mode of PrV cell death in the embryonic and newborn $\mathrm{DRG}^{-/-}$, hundreds of cells from each of 30 (16 mutant, 14 wild-type) cases were viewed in the electron microscope. Conventional criteria (Clarke, 1990; Wüllner et al., 1999) were applied in designating a nuclear profile as neuronal and being intact or undergoing apoptosis or necrosis Neuronal profiles were considered apoptotic if they displayed cell shrinkage, membrane blebbing, swelling or mitochondrial shrinkage, and condensation of cytoplasm and chromatin, nuclear pyknosis, and cell fragmentation into apoptotic bodies. Necrotic profiles displayed extreme mitochondrial swelling and damaged cellular and nuclear membranes. To estimate the prevalence (density) of dying PrV cells in these same cases, electron microscopic analysis of grid squares containing the $\operatorname{PrV}$ was performed using previously described stereological methods (Golden et al., 1997). All apoptotic and necrotic cell bodies were counted within each grid square. Blood capillary areas were subtracted from the total tissue areas. In those tissue sections in which the integrity of the tissue precluded a definitive classification, serial ultrathin sections were taken and viewed so as to reconstruct questionable somatic profiles. In addition, for the E14-E18 cases, all degenerating axonal and dendritic profiles, as well as intact axon terminals and synapses, were counted according to previously described criteria (Golden et al., 1997). Their density in the mutant and control PrV was estimated by the use of abovedescribed stereological methods.

Whisker-related patterning in cytochrome oxidase-stained sections through the brainstem was qualitatively evaluated by the use of previously described methods (Henderson et al., 1994).

Cell number and volume estimates in the $\mathrm{V}$ ganglia and $\mathrm{PrV}$, and when available, the SpVi, were subjected to statistical analyses. A multifactor ANOVA was performed that considered genotype, neuronal structure, and age as independent variables. When justified based on significant $(p<0.05)$ main effects, post hoc comparisons were performed between experimental groups (genotypes) by the use of Newman-Keuls tests that correct for multiple comparisons. Significant differences were considered at $p$ values $<0.05$. Sample sizes are also listed in the illustrations and legends.

\section{Results}

\section{Cytoarchitecture}

At first glance, the gross morphology of the $\mathrm{V}$ ganglion, $\mathrm{PrV}$, and $\mathrm{SpVi}$ were indistinguishable between the various genotypes considered here on the day of birth (Figs. 1,2). Closer inspection of 
Wildtype
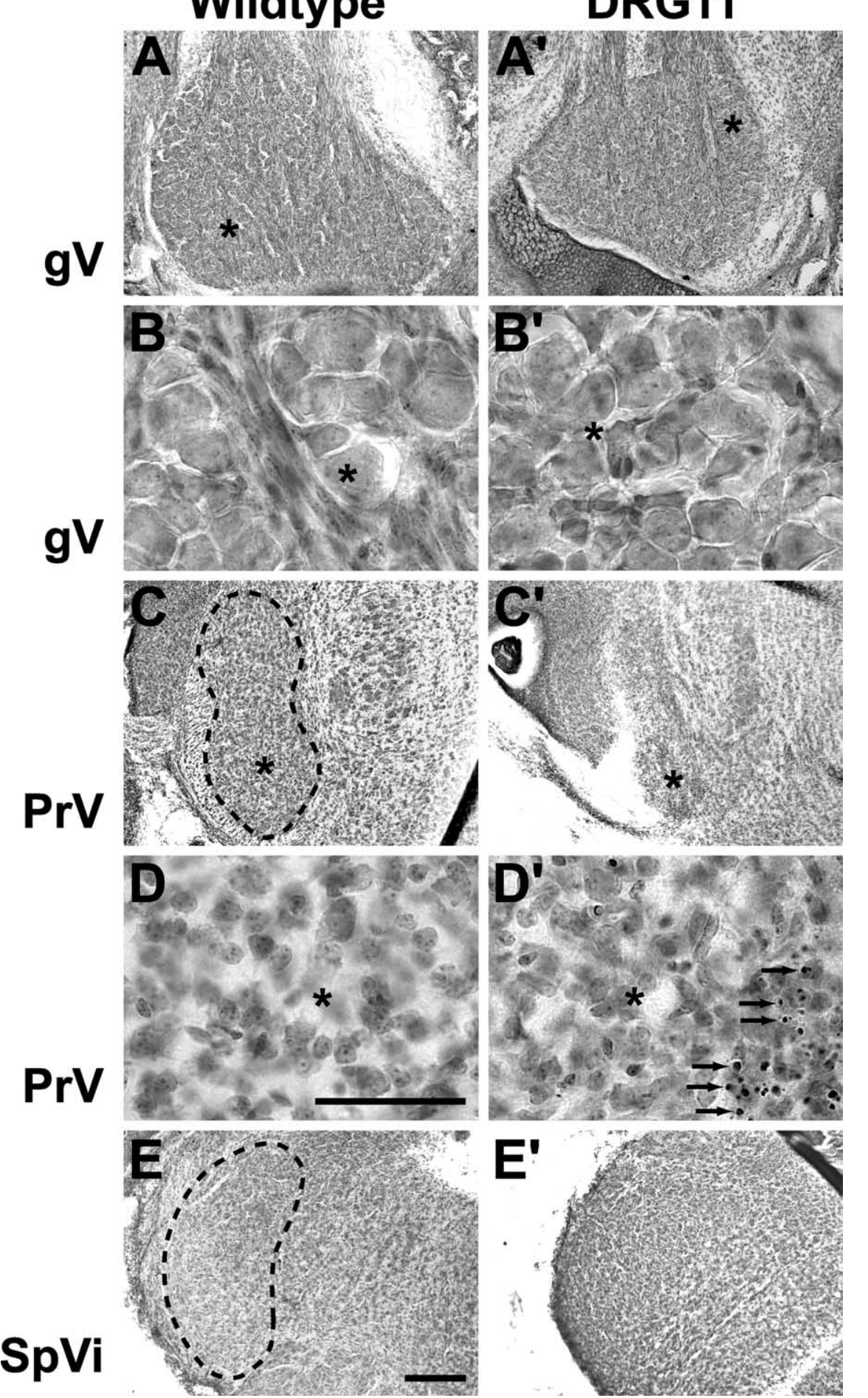

DRG11 ${ }^{-1-}$

\section{tur} ture predicted variance in estimates of neuron numbers in the PrV, SpVi, and V ganglion. Figure 3 contains all of the quantitative estimates of cell numbers, in which robust decreases were obtained in the $D R G 11^{-/-}$cases, relative to wild-type controls. Bax/DRG11 double $-/-$ mice had normal cell numbers, as did Bax single - /- cases. The latter impression prompted analyses of these same V structures in $\mathrm{Bax}^{-1-}$ embryos at E17, in which greater than normal numbers were obtained.

Main effects for genotype $(F=47)$, age $(F=26)$, and structure $(F=660)$ were all statistically reliable at the $p<0.00001$ level. Significant interactions were also revealed between genotype and structure, structure and age, genotype and age, and structure/genotype/age $(p=0.0000$, $0.0000,0.0019$, and 0.0028 , respectively). Post hoc comparisons revealed significant differences $(p<0.05)$ between $D R G 11^{-/-}$ and wild-type mice at birth in all three $\mathrm{V}$ structures examined, between $\mathrm{Bax}^{-/-}$and wild-type mice on E17 in the PrV and V ganglion only, and between $\mathrm{Bax}^{-1-}$ and wild-type mice at birth in the SpVi only. DRG11/Bax double - / - mice at birth had total cell numbers in the PrV and V ganglia that did not differ from age-matched wildtype controls. Relevant post hoc paired comparisons also revealed significant $(p<$ $0.05)$ differences in cell numbers between the following experimental groups: $B a x^{-/-}$at birth versus $B a x^{-/-}$E17 V ganglia and $D R G 11^{-/-}$versus $D R G 11 / B a x$ double $-/-\operatorname{PrV}$ and $\mathrm{V}$ ganglia. The latter indicates significant $\mathrm{Bax}^{-/-}$-induced rescue of $\mathrm{PrV}$ and ganglion cells that otherwise die in the DRG11 single $-/-$ mice. Moreover, the three $\mathrm{V}$ structures examined in DRG $11^{-1-}$ cases did not statistically differ in the extent of their cell loss relative to wild-type controls.
Figure 1. Photomicrographs of cresyl violet-stained horizontal sections through the trigeminal ganglion ( $\mathrm{gV}$ ) and coronal sections through the PrV and SpVi. All panels are from mice on the day of birth. The left column illustrates wild-type controls; the right column shows material from $D R G 11^{-/-}$cases. $\boldsymbol{B}$ and $\boldsymbol{B}^{\prime}$ are higher-magnification views of $\boldsymbol{A}$ and $\boldsymbol{A}^{\prime}$, with asterisks indicating matching areas in each image pair. $\boldsymbol{D}$ and $\boldsymbol{D}^{\prime}$ provide higher magnification of $\boldsymbol{C}$ and $\boldsymbol{C}^{\prime}$, in which the $\operatorname{PrV}$ is outlined. Arrows in $\boldsymbol{D}^{\prime}$ indicate pyknotic cells and apoptotic debris. The SpVi is outlined in $\boldsymbol{E}$. Scale bars: (in $\left.\boldsymbol{E}\right) \boldsymbol{A}, \boldsymbol{A}^{\prime}, \boldsymbol{C}, \boldsymbol{C}^{\prime}, \boldsymbol{E}^{\prime}, 200 \mu \mathrm{m}$; (in D) $B, B^{\prime}, D^{\prime}, 50 \mu \mathrm{m}$.

\section{Cell sizes}

the $D R G 11^{-/-}$cases, however, revealed that these three V structures were somewhat smaller than their counterparts in wild-type controls (Fig. 1, $A$ vs $A^{\prime}, C$ vs $C^{\prime}, E$ vs $E^{\prime}$ ), as illustrated previously (Ding et al., 2003). Only the PrV in DRG11 ${ }^{-/-}$displayed anom-
Because a previous study (Rebelo et al., 2006) of DRG11 ${ }^{-/-}$spinal dorsal root ganglia indicated that small cells were disproportionately lost by the end of the first postnatal week, a similar analysis of $\mathrm{V}$ ganglion cells was performed here. As shown in 
Figure 4 , in newborn $D R G 11^{-/-}$cases, the distribution of $\mathrm{V}$ ganglion cell volumes shifted toward a disproportionate representation of larger cells, with the modal size occurring in the 3000-4000 $\mu^{3}$ bin, whereas in the wild-type, $B a x^{-/-}$, and $B a x /$ DRG11 double - / - cases the modal size occurred in the 2000-3000 $\mu^{3}{ }^{3}$ bin. ANOVA revealed a significant genotype main effect for cell volume. Post hoc comparisons indicated that the DRG11 group had reliably larger $\mathrm{V}$ ganglion cells than those of the wild-type group and that the $\mathrm{Bax}^{-1-}$ and Bax/Drg11 double -/ganglion cells had the same size distribution as those of wild-type controls. Also note that the smallest ganglion cell category, up to $1000 \mu \mathrm{m}^{3}$, was reliably detected in significant numbers and considered in all such analyses of the aforementioned four genotypes.

\section{Cell death}

An electron microscopic study was performed to document the mechanism, prevalence, and time course of cell death in the DRG11 ${ }^{-/-}$PrV. Apoptosis was found to be such a prevalent mechanism (Figs. 5, 6) because most of the degenerating PrV neurons had condensed chromatin within their nuclei and other above-listed apoptotic features (see Materials and Methods). Often they were juxtaposed to an astrocyte with processes that apposed the degenerating cell. These identifying features indicate that these cells are undergoing apoptosis in the mutant PrV. The prevalence of apoptosis and necrosis, in which severe shrinkage of the cell body and its increased electron density occurred, was quantified by stereological electron microscopic analysis performed blind to genotype. From the 30 cases so quantified on E14, E16, E18, and $\mathrm{P} 0$, degenerating somata were found to be most numerous on E18 and P0 (Fig. 7A). The largest differential between experimental and control groups occurred on E18, in which degenerating cell bodies were, on average, six times more prevalent in the DRG11 ${ }^{-/-}$PrV than in wild-type controls. By P0, this differential had fallen to three times more prevalent, in part reflecting the increased incidence of apoptosis and necrosis in the control PrV.

By the use of previously published criteria (Golden et al., 1997, their illustrations), degenerating profiles were then considered, inclusive of any component of axons and dendrites but exclusive of somata (Fig. $7 B$ ). Here, significant differences between the mutant and wild-type PrV were obtained on E14, E16, and E18, indicating that "distal" degenerative events were more prevalent in the DRG11 ${ }^{-/-}$well in advance (E14, E16) of when a significantly increased apoptotic cell body density was

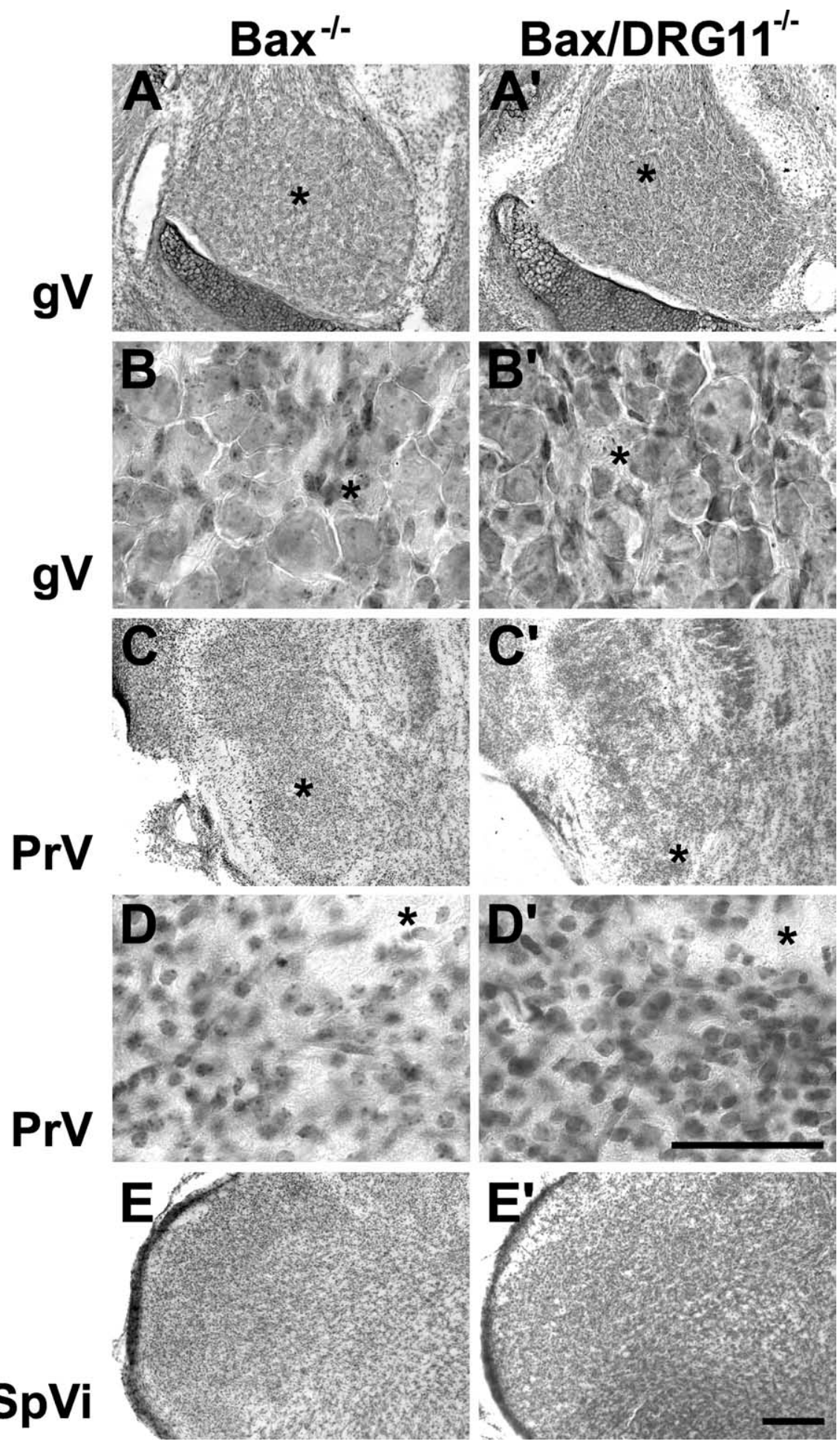

Figure 2. Photomicrographs of horizontal sections through the $\mathrm{gV}\left(\boldsymbol{A}-\boldsymbol{B}^{\prime}\right)$ and coronal sections through the $\operatorname{PrV}\left(\boldsymbol{C}-\boldsymbol{D}^{\prime}\right)$ and $\operatorname{SpVi}\left(\boldsymbol{E}, \boldsymbol{E}^{\prime}\right)$ from $\mathrm{Bax}^{-/-}$and Bax/DRG11 double $-/-$cases on the day of birth. All conventions are as in Figure 1.

detected (E18). This increased density of degenerating profiles was reflected in a significantly reduced density of intact axon terminals (Fig. 7C) and synapses (Fig. 7D) in the mutants relative to wild-type controls on E14-E18. Thus, "subtle" degenerative changes in the PrV ultrastructure occurred at least $4 \mathrm{~d}$ before the embryonic age (E18) when abundant apoptosis was detected, as well as $4 \mathrm{~d}$ before when whisker-related patterns are first visible in the normal PrV, E18 (Chiaia et al., 1992) (our unpublished data). 


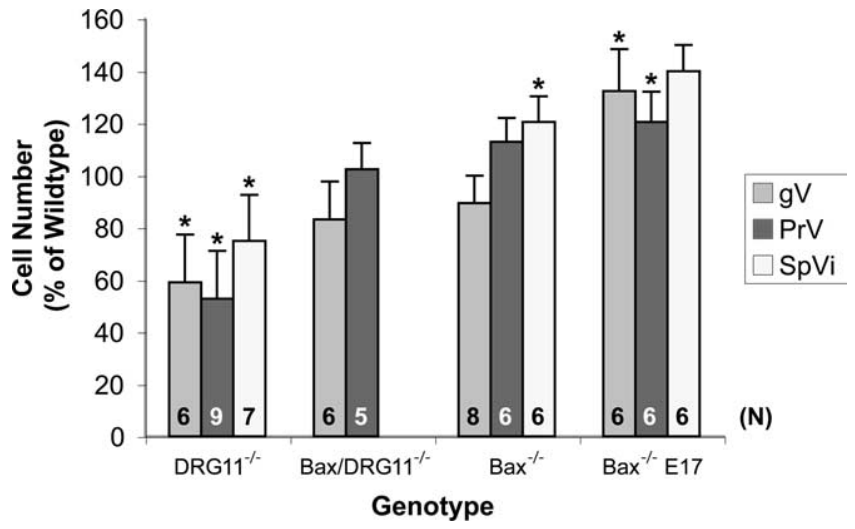

Figure 3. Histogram of mean ( $\pm S D$ ) cell numbers in the V ganglion ( $g$ V), PrV, and SpVi from DRG11 ${ }^{-/-}$, Bax/DRG11 double $-/-$, and $\mathrm{Bax}^{-/-}$cases on the day of birth and $\mathrm{Bax}{ }^{-/-}$mice on $\mathrm{E} 17$ as percentages of values obtained from wild-type control cases at matching ages. These wild-type values at birth are 40,829 $\pm 3755(n=8), 48,337 \pm 7030(n=9)$, and $6258 \pm$ $1722(n=8)$ for the ganglion, $\operatorname{PrV}$, and SpVi, respectively; on E17, these respective values $(n=$ 6 each) are 36,784 $\pm 5083,32,314 \pm 6494$, and $2639 \pm 669$. Sample sizes ( $n$ ) contributing experimental data for each structure in each experimental group are indicated within their respective bars. Note that ganglion and PrV cell numbers reflect the entirety of these structures based on stereological estimates; SpVi numbers reflect the numbers of cell profiles counted in one coronal section at the level of the obex. ${ }^{*} p<0.05$, significantly different from wild-type control values.

\section{Pattern formation}

Two observations are relevant to the hypothesis that excess cell death is sufficient to explain failed whisker-related pattern formation in the DRG11 $1^{-1-}$ PrV. First, PrV and SpVi displayed equivalent and significant cell loss (Fig. 3), whereas whiskerrelated patterns were observed in the SpVi but not in the PrV (Ding et al., 2003, their Fig. 5). Second, although PrV and V ganglion cells were rescued in the DRG11/Bax double null mutants (Fig. 3), the latter cases failed to develop whisker-related patterns in the newborn PrV (Fig. $8 A-C$ ) but did so in the SpVi (Fig. $8 D, E$ ). Therefore, the brainstem patterning deficit in the double null mutants was equivalent to that of the DRG11 single null mutants.

\section{Discussion}

Previous studies (Chen et al., 2001; Ding et al., 2003; Wang et al., 2007) indicate that the mouse DRG11 gene is expressed in the developing spinal dorsal root ganglia and dorsal horn, $\mathrm{V}$ ganglion, mesencephalic V nucleus, and PrV. There is a suggestion (Rebelo et al., 2006) that DRG11 selectively sustains "small" dorsal root ganglion cells that tend to be nociceptors, consistent with its expression in the superficial dorsal horn (Chen et al., 2001). However, the expression of DRG11 in the entire size range of $\mathrm{V}$ ganglion cells and mesencephalic $\mathrm{V}$ proprioceptors, along with its expression in the PrV (but not the SpVi), which exclusively receives large-caliber mechanoreceptor inputs (Shortland et al., 1996), suggest additional DRG11 functions in the V system beyond sustaining small ganglion cells. Data presented here and previously (Ding et al., 2003; Wang et al., 2007) suggest that $D R G 11$ is necessary for the survival of $\mathrm{V}$ mesencephalic proprioceptors and that DRG11 has an indispensable function in whisker-related pattern formation in the PrV by some mechanism other than ensuring neuronal survival.

\section{Cell survival}

Many V neurons require DRG11 for survival. In $D R G 11^{-/-}$mice at birth, V ganglion, PrV, and SpVi cell estimates are 59, 53, and
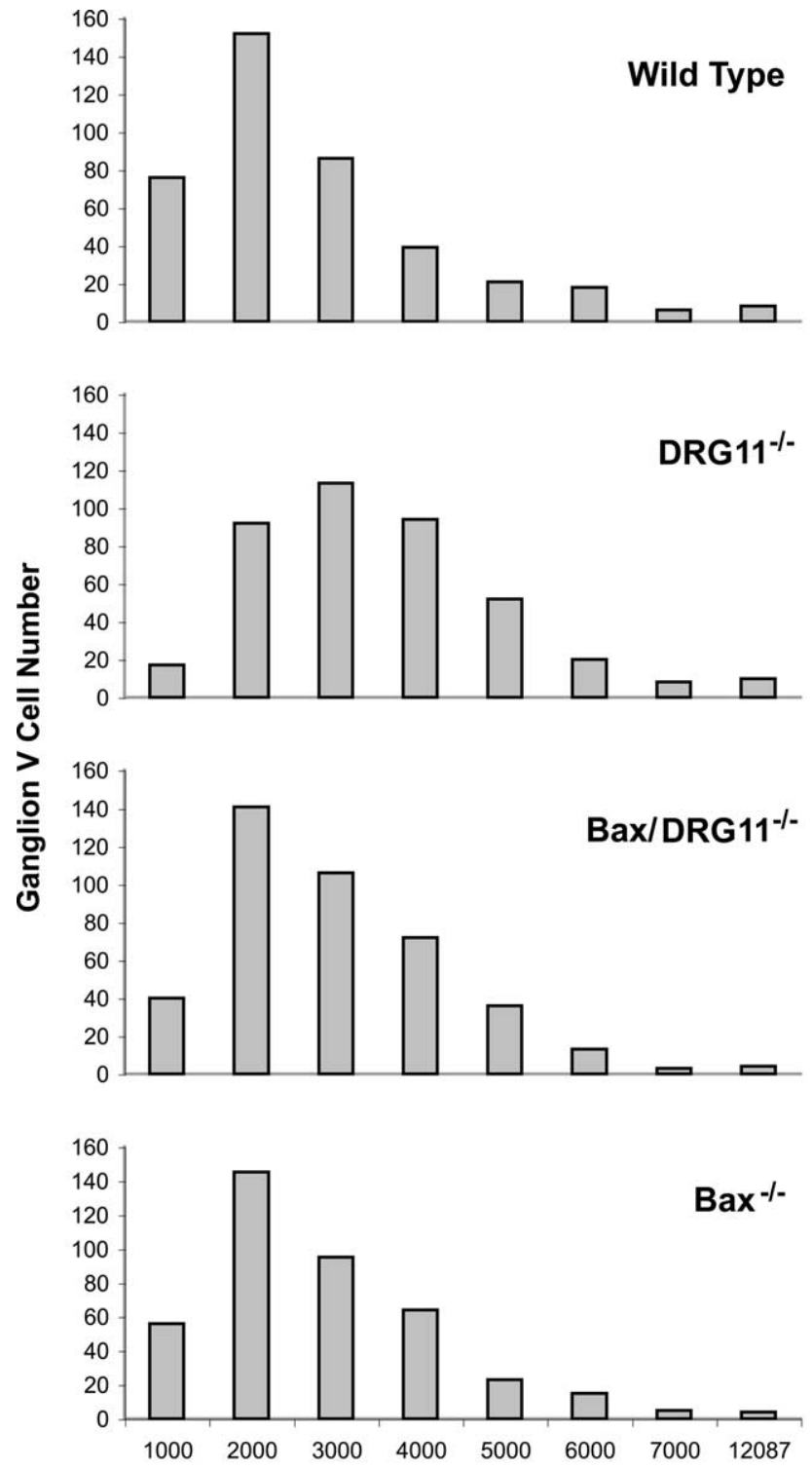

Ganglion V Cell Volume $\left(\mu \mathrm{m}^{3}\right)$

Figure 4. Distribution of $\mathrm{V}$ ganglion cell sizes (volumes) from wild-type, $D R G 11^{-/-}, \mathrm{Bax} /$ DRG11 double $-/-$, and $\mathrm{Bax}^{-/-}$cases on the day of birth. Volume bins encompass 1000 $\mu \mathrm{m}^{3}$, except for the lowest bin $\left(<1000 \mu \mathrm{m}^{3}\right)$ and the highest bin (maximum values ranging from $7917 \mu \mathrm{m}^{3}$ for $D R G 11^{-1-}$ to $12,078 \mu \mathrm{m}^{3}$ for wild type). Sample sizes are as follows: wild type, $n=5 ;$ DRG11 ${ }^{-1-}, n=5 ;$ Bax/DRG11 double $-/-, n=4 ; \mathrm{Bax}^{-/-}, n=3$. A total of 409 neurons were randomly chosen and assessed for each genotype.

$75 \%$ of normal, on average. Because Ding et al. (2003) showed that $\mathrm{PrV}$ cell generation, migration, and differentiation were normal in DRG11 ${ }^{-1-}$ embryos and that unusual PrV cell death was not detected until E16.5, excessive V brainstem cell death likely occurs after the $\mathrm{V}$ nuclei are formed. Moreover, reduced cell numbers in the $\mathrm{SpVi}$, in which DRG11 is not expressed, suggest that some of the cell loss in the SpVi and PrV reflects ganglion cell death-induced deafferentation (Henderson et al., 1993). Greater cell loss in the PrV than in SpVi also suggests that some PrV cell death is a direct effect of the DRG11 deletion. This conjecture is supported by our observations (C. Xiang, J. A. Arends, M. F. Jacquin, and Z.-F. Chen, unpublished observations) of similar PrV cell loss in knock-out preparations targeting a transcription 
factor, $L m x 1 b$, that signals upstream of DRG11 and is not expressed in the $\mathrm{V}$ ganglion.

DRG11 can now be added to the short list of transcriptional regulators implicated in $\mathrm{V}$ ganglion cell survival. Brn3a-deficient mice display extensive apoptosis in the $\mathrm{V}$ ganglion during late embryonic development (McEvilly et al., 1996; Huang et al., 1999). Similarly, cAMP-responsive element-binding protein (CREB) sustains $\mathrm{V}$ ganglion neurons via its transcriptional activity induced by neurotrophins (Ginty et al., 1994; Bonni et al., 1995, 1999; Finkbeiner et al., 1997). The causal link between CREB activity and neurotrophins suggests that CREB is also active during late embryonic development. Thus, like DRG11, Brn3a and CREB appear to be important for ganglion cell survival days after the ganglion cells are generated. This differs from the transcription factors Six 1 and Six6, which exhibit survival functions during V gangliogenesis (Konishi et al., 2006). The present study expands the list of structures for which transcription factors exhibit cell survival functions to the PrV and SpVi. Qian et al. (2002) reported that PrV neurons depend on two related homeobox genes, $T l x-3$ and $T l x-1$, for proper development and that $T l x-3$ and $T l x-1$ maintain expression of DRG11. Whether these transcription factors serve redundant functions within the same signaling pathway is unknown.

Ultrastructural observations indicate that the main mechanism of DRG11 $1^{-1-}$ induced PrV cell death is apoptosis. This conclusion is supported by the "rescue" of PrV cells in Bax/DRG11 double mutants.
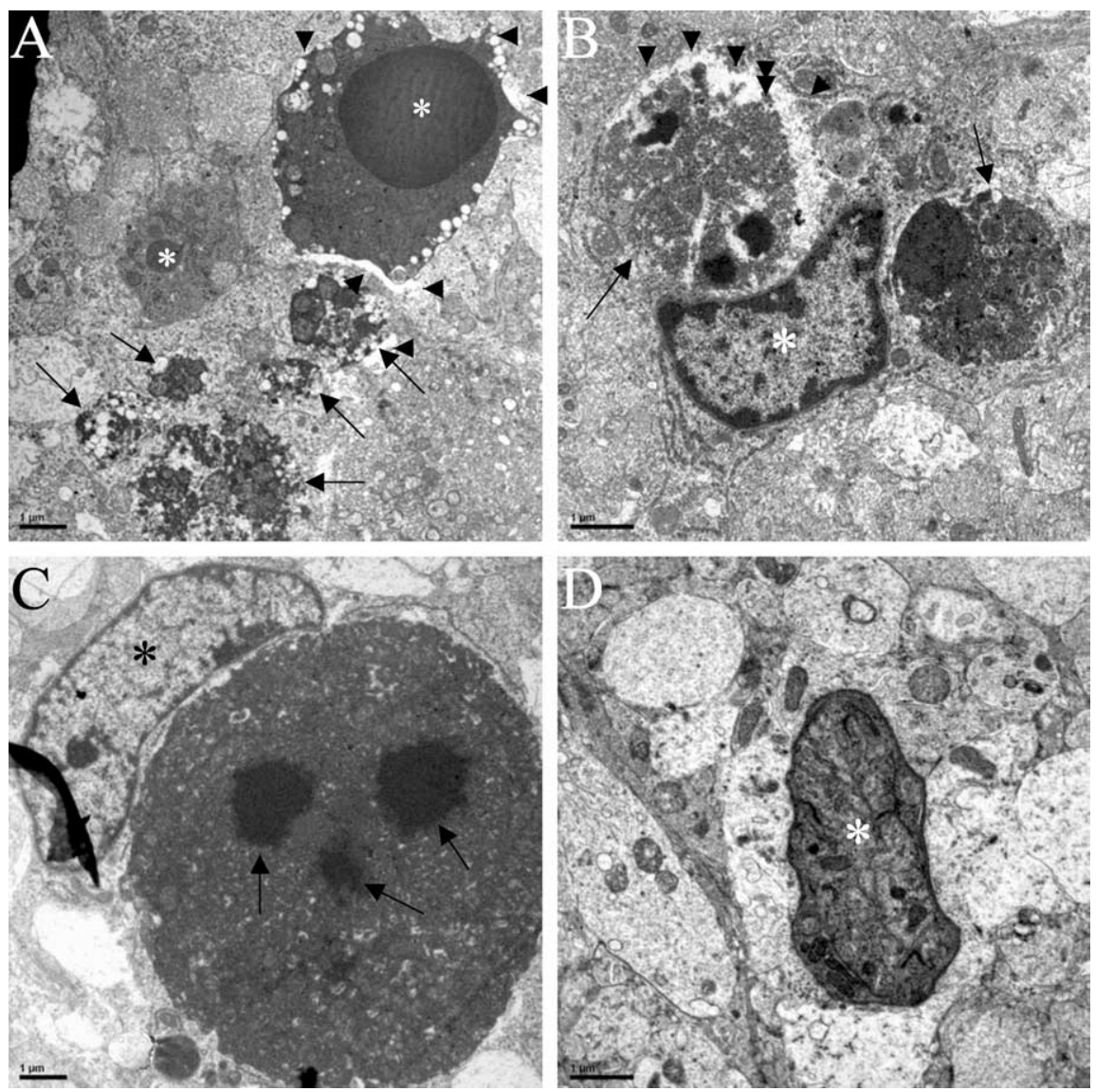

Figure 5. Ultrastructure of dying neurons and associated cells in the newborn PrV of DRG11 ${ }^{-/-}$mice. Both apoptotic and necrotic mechanisms of cell death are illustrated here from one representative case. $A$, Low-magnification view of two apoptotic neurons (asterisks) and several necrotic cells (arrows). Note the condensed chromatin of the nucleus in the larger apoptotic neuron at the top. This neuron is also surrounded by an astrocytic process containing few organelles (arrowheads). The necrotic cells have disrupted or nonexistent cell membranes. $\boldsymbol{B}$, Dying cells are often apposed by an astrocyte (asterisk) that is possibly involved in phagocytosis of the dying cells; note the astrocytic process containing few organelles (arrowheads) surrounding the cell on top. C, Another dying cell has three electron-dense bodies within its condensed chromatin (arrows); this cell is apposed to an astrocyte (asterisk) whose processes surround a large portion of the surface of this cell body. D, A dying cell (asterisk) is shown among a field of well preserved dendritic profiles, indicating the selectivity of the dying cell bodies. Scale bars, $1 \mu \mathrm{m}$.
Hallmark indicators of apoptosis were ob-

served, including cell shrinkage, extracellular membrane blebbing, and condensation of the nuclear chromatin into apoptotic bodies with intact cell and nuclear membranes. The proximity of putative astrocyte cell bodies and processes to dying PrV cells suggests that astrocytes may have a role in the death or removal of apoptotic cells. Moreover, because apoptotic profiles were numerous at birth, our light microscopically derived cell counts, in tissues harvested at birth, undoubtedly underestimate the longerterm diminution of $\mathrm{V}$ neurons.

Comparisons between $\mathrm{V}$ and dorsal root ganglia loss in DRG11 mutants are now in order. Rebelo et al. (2006) found that total numbers of dorsal root ganglion cells in DRG11 mutants did not differ from those of controls on E14.5, E18.5, and P0, yet significant loss of cells was noted on P7, P14, and adulthood. This inconsistency with the present study may reflect the more rapid development of the V system than the spinal system. Indeed, the dorsal root ganglion cell loss reported on $\mathrm{P} 7$ is equivalent to the $\mathrm{V}$ cell loss reported here on P0. Perhaps more notable is the finding by Robelo et al. that the postnatal death of dorsal root ganglion cells is restricted to the cell classes that express CGRP (calcitonin gene-related peptide) and IB4, i.e., the cells destined to perform a nociceptive function and tend to be smaller in size than the mech- anoreceptors. Cell size analysis included here indicates a similar loss of the smaller ganglion cells, suggesting that the same cell categories die in dorsal root and V ganglia in DRG11 mutants.

A somewhat surprising secondary observation was the normal $\mathrm{V}$ ganglion and $\mathrm{PrV}$ cell numbers in $\mathrm{Bax}^{-/-}$mice at birth, whereas excess ganglion cell numbers were observed on E17. This stands in contrast to previous reports (Deckwerth et al., 1996; White et al., 1998; Lentz et al., 1999), indicating that, in Bax ${ }^{-/-}$ mice, $\mathrm{V}$ and spinal ganglion cells rescued from naturally occurring cell death are maintained for significant postnatal periods. The reason for this discrepancy is unclear, although there is no question that the $\mathrm{Bax}^{-/-}$strain used here displayed a phenotype at birth because, when crossed with DRG11 heterozygotes, resultant double null mutants had normal numbers of $\mathrm{V}$ ganglion and PrV cells, unlike the DRG11 single null cases. Moreover, cell counting methods used here reliably detected the smallest of $\mathrm{V}$ ganglion and PrV cells, some of which might have been atrophic as a result of the Bax mutation (Buss et al., 2006), although ganglion cell sizes did not differ between the Bax and wild-type strains studied here. Perhaps differing cell counting methods account for these discrepant results. Additional studies are required to address our suggestion that Bax may not necessary for execu- 


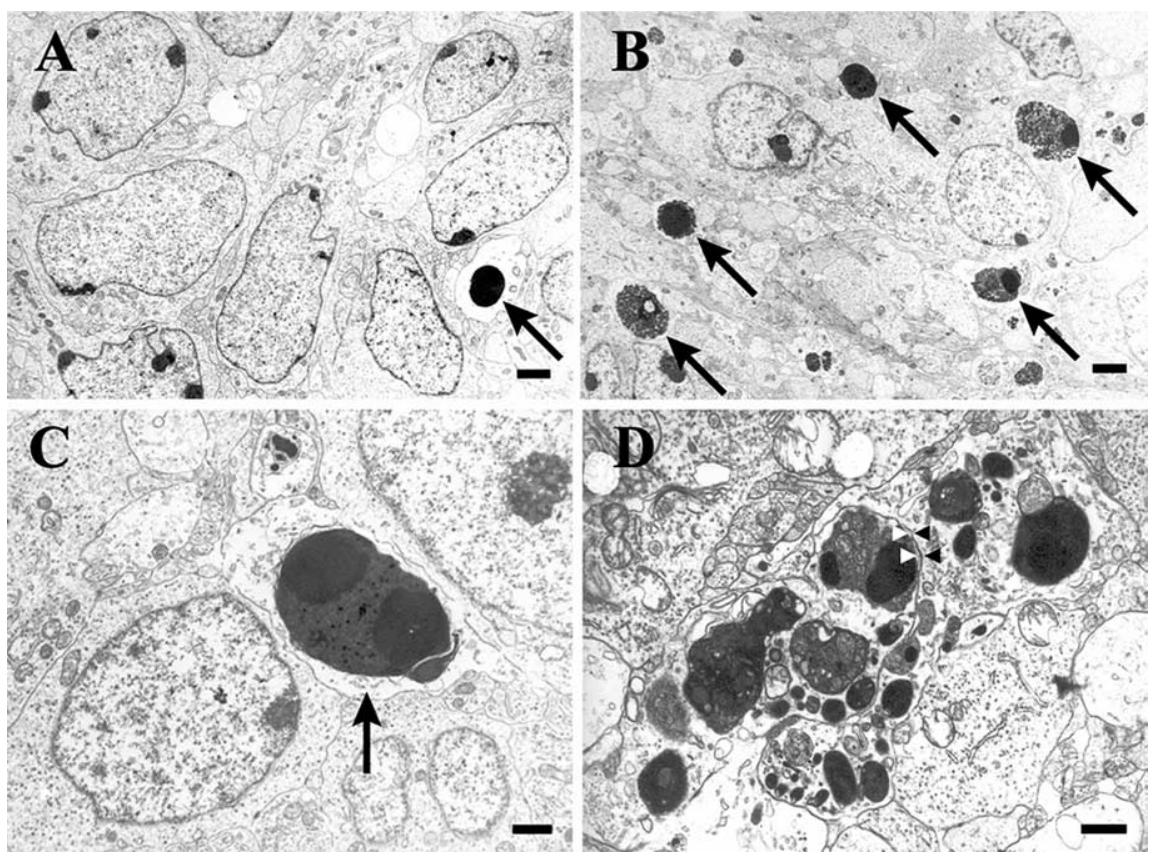

Figure 6. Electron microscopy was used to reveal unusually abundant apoptosis in the E18 PrV of DRG11 ${ }^{-/-}$mice $(\boldsymbol{B}-\boldsymbol{D})$, relative to wild-type controls at the same age $(\boldsymbol{A})$. At higher magnification in $\boldsymbol{C}$ and $\boldsymbol{D}$, early and late stages of apoptosis are seen. $A-D$, Arrows are used here to indicate some of the electron-dense apoptotic bodies. In $D$, numerous apoptotic bodies are found in two neighboring somata that appear to be in a late stage of apoptosis. Each soma in this panel was defined as a single apoptotic cell based on its surrounding membrane. Membranes (arrowheads) separate the two individual profiles in this section. Scale bars: $A, B, 2 \mu \mathrm{m} ; C, D, 1 \mu \mathrm{m}$.

tion of the apoptotic cascade in otherwise normal embryonic $\mathrm{V}$ ganglion and PrV cells but that Bax is necessary for their apoptosis in $D R G 11^{-/-}$mice.

\section{Pattern formation}

Perhaps the most compelling feature of the DRG11 ${ }^{-/-}$mouse is the absence of barrelettes, barreloids, and barrels in the whiskerrelated "lemniscal" pathway (Ding et al., 2003). The same animals display normal somatotopic patterns in limb-related lemniscal nuclei and in whisker-related SpV "paralemniscal" structures. Such selectivity in a patterning anomaly within a single sensory system strongly suggests that the DRG11 gene functions specifically in the development of the $\mathrm{V}$ lemniscal pathway.

The present study asked whether extensive cell death produced by the DRG11 mutation can singularly account for the absence of whisker-related patterning in the PrV. Three conclusions are warranted. First, V ganglion cell death is insufficient to explain failed PrV patterning because virtually all $\mathrm{V}$ ganglion cells that project to the PrV also project to the SpVi (Shortland et al., 1996), and the mutant SpVi is normally patterned. Thus, SpVi patterns develop normally in the face of $40 \%$ ganglion cell death. The latter observation is reminiscent of a previous report (Sikich et al., 1986), indicating that CNS whisker-related patterns develop in guinea pigs when up to $80 \%$ of their $\mathrm{V}$ ganglion cells are killed by embryonic anti-nerve growth factor injections. Second, $\mathrm{PrV}$ cell death is insufficient to explain failed PrV patterning because statistically equivalent cell death in the mutant SpVi fails to preclude patterning there and because $\mathrm{Bax}^{-1-}$-induced $\mathrm{PrV}$ cell rescue fails to rescue PrV pattern formation. With regard to the latter, others have shown that neurons rescued from apoptosis by Bax deletion can be atrophic (Buss et al., 2006). This is unlikely to account for failed pattern formation in Bax/ $D R G 11^{-/-}$cases because their $\mathrm{V}$ ganglion cell size distribution does not differ from wild-type controls. Third, DRG11 is part of a transcriptional signaling pathway that makes barrelettes in the PrV. How DRG11 does this is unknown. Recently, we (Xiang, Arends, Jacquin, and Chen, unpublished observations) found that deletion of $L m x 1 b$, a transcription factor acting upstream of DRG11, produces identical effects on the $\mathrm{PrV}$ to those detailed here. Whether $L m \times 1 b$ and consequent DRG11 activity engage other known PrV patterning factors, such as the NMDA NR1 receptor subunit Hoxa2 and possibly various ephrin axon guidance molecules is unknown.

Thus, the present study refutes the hypothesis that $\mathrm{V}$ cell death causes failed $\mathrm{PrV}$ pattern formation in DRG11 ${ }^{-/-}$mice. Perhaps the converse is true; maybe failed PrV patterning produces cell death. Barrel-like patterns may provide a dense source of trophic substances that are necessary to sustain an unusually large number of cells processing inputs from a single whisker, commensurate with the high innervation density of the whisker. This idea is supported by the fact that all known lesions (Jacquin et al., 1993, 1996), trophic factor manipulations (Henderson et al., 1994), or mutations (Li et al., 1994; Ding et al., 2003) that interrupt $\operatorname{PrV}$ pattern formation also result in a smaller than normal PrV.

\section{References}

Barnett MW, Watson RF, Vitalis T, Porter K, Komiyama NH, Stoney PN, Gillingwater TH, Grant SGN, Kind PC (2006) Synaptic Ras GTPase activating protein regulates pattern formation in the trigeminal system of mice. J Neurosci 26:1355-1365.

Bates CA, Killackey HP (1985) The organization of the neonatal rat's brainstem trigeminal complex and its role in the formation of central trigeminal patterns. J Comp Neurol 240:265-287.

Bennett-Clarke CA, Leslie MJ, Lane RD, Rhoades RW (1994) Effect of serotonin depletion on vibrissa-related patterns of thalamic afferents in the rat's somatosensory cortex. J Neurosci 14:7594-7607.

Bonni A, Ginty DD, Dudek H, Greenberg ME (1995) Serine 133phosphorylated CREB induces transcription via a cooperative mechanism that may confer specificity to neurotrophin signals. Mol Cell Neurosci 6:168-183.

Bonni A, Brunet A, West AE, Datta SR, Takasu MA, Greenberg ME (1999) Cell survival promotoed by the Ras-MAPK signaling pathway by transcription-dependent and -independent mechanisms. Science 286:1358-1362.

Buss RR, Gould TW, Ma J, Vinsant S, Prevette D, Winseck A, Toops KA, Hammarback JA, Smith TL, Oppenheim RW (2006) Neuromuscular development in the absence of programmed cell death: phenotypic alteration of motoneurons and muscle. J Neurosci 26:13413-13427.

Cases O, Vitalis T, Self I, De Maeyer E, Sotelo C, Gaspar P (1996) Lack of barrels in the somatosensory cortex of monoamine oxidase A-deficient mice: role of a serotonin excess during the critical period. Neuron 16:297-307.

Chen ZF, Rebelo S, White F, Malmberg AB, Baba H, Lima D, Woolf CJ, Basbaum AI, Anderson DJ (2001) The paired homeodomain protein DRG11 is required for the projection of cutaneous sensory afferent fibers to the dorsal spinal cord. Neuron 31:59-73.

Chiaia NL, Bennett-Clarke CA, Eck M, White FA, Crissman RS, Rhoades RW (1992) Evidence for prenatal competition among the central arbors of trigeminal primary afferent neurons. J Neurosci 12:62-76. 

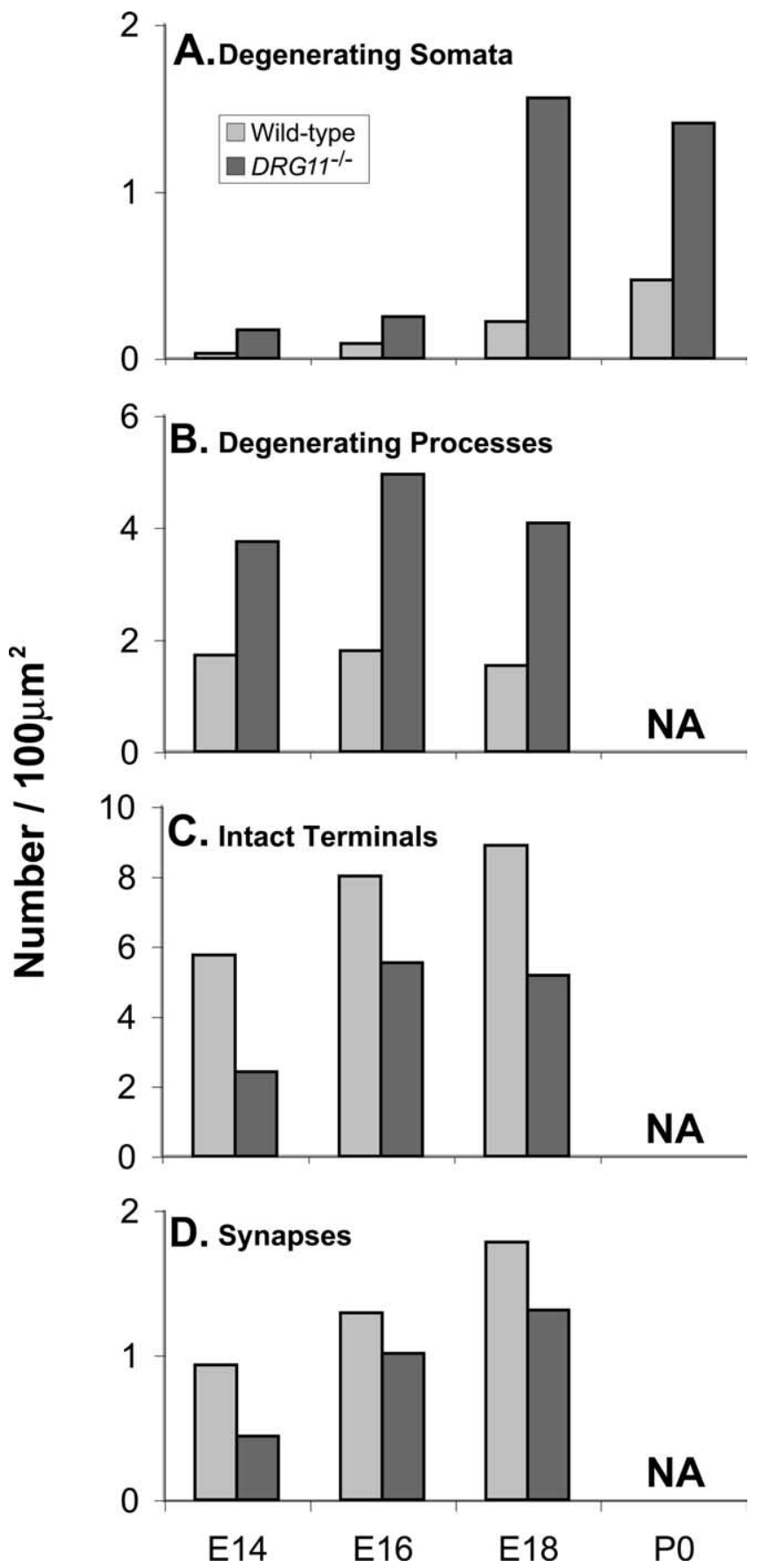

Figure 7. Stereological estimates of the prevalence of indicated ultrastructural features of the PrV in DRG11 ${ }^{-1-}$ embryos at the time points indicated, relative to wild-type control littermates. NA, Data not available. Sample sizes are as follows: $\mathrm{DRG}_{11^{-/-}}, \mathrm{E} 14, n=2 ; \mathrm{E} 16, n=4$; $\mathrm{E} 18, n=5-6$; wild-type, E14, $n=2-4 ; \mathrm{E} 16, n=2-4 ; \mathrm{E} 18, n=2-4$.

Clarke PG (1990) Developmental cell death: morphological diversity and multiple mechanisms. Anat Embryol 181:195-213.

Deckwerth TL, Elliott JL, Knudson CM, Johnson EM, Snider WD, Korsmeyer SJ (1996) Bax is required for neuronal death after trophic factor deprivation and during development. Neuron 17:401-411.

Ding YQ, Yin J, Xu HM, Jacquin MF, Chen ZF (2003) Formation of whisker-related principal sensory nucleus-based lemniscal pathway requires a paired homeodomain transcription factor, Drg11. J Neurosci 23:7246-7254.

Erzurumlu RS, Chen ZF, Jacquin MF (2006) Molecular determinants of the face map development in the trigeminal brainstem. Anat Rec 288:121-134.

Finkbeiner S, Tavazoie SF, Maloratsky A, Jacobs KM, Harris KM (1997)
CREB: a major mediator of neuronal neurotrophin responses. Neuron 19:1031-1047.

Fukucki-Shimogori T, Grove EA (2001) Neocortex patterning by the secreted signaling molecule FGF8. Science 294:1071-1074.

Ginty DD, Bonni A, Greenberg ME (1994) Nerve growth factor activates a Ras-dependent protein kinase that stimulates $c$-fos transcription via phosphorylation of CREB. Cell 77:713-725.

Golden JP, DeMaro JA, Jacquin MF (1997) Postnatal development of terminals and synapses in laminae I and II of the rat medullary dorsal horn. J Comp Neurol 383:326-338.

Gunderson HJG (1987) The efficiency of systematic sampling in stereology and its prediction. J Microsc 147:229-263.

Hannan AJ, Blakemore C, Katsneson A, Vitalis T, Huber KM, Bear M, Roder J, Kim D, Shin HS, Kind PC (2001) Phospholipase C- $\beta 1$, activated via MGluRs, mediates activity-dependent differentiation in cerebral cortex. Nat Neurosci 4:282-288.

Henderson TA, Jacquin MF (1995) What makes subcortical barrels? Requisite trigeminal circuitry and developmental mechanisms. Cereb Cortex 11:123-187.

Henderson TA, Rhoades RW, Bennett-Clarke CA, Osborne PA, Johnson EM, Jacquin MF (1993) NGF augmentation rescues trigeminal ganglion and principalis neurons, but not brainstem or cortical whisker patterns, after infraorbital nerve injury at birth. J Comp Neurol 336:243-260.

Henderson TA, Johnson EM, Osborne PA, Jacquin MF (1994) Fetal NGF augmentation preserves excess trigeminal ganglion cells and interrupts whisker-related pattern formation. J Neurosci 14:3389-3403.

Huang EG, Zang K, Schmidt A, Saulys A, Xiang M, Reichardt LF (1999) POU domain factor Brn-3a controls the differentiation and survival of trigeminal neurons by regulating Trk receptor expression. Development 126:2869-2882.

Inan M, Lu HC, Albright MJ, She WC, Crair MC (2006) Barrel map development relies on protein kinase A regulatory subunit II beta-mediated cAMP signaling. J Neurosci 26:4338-4349.

Iwasato T, Erzurumlu RS, Huerta PT, Chen DF, Sasaoka T, Ulupinar E, Tonegawa S (1997) NMDA receptor-dependent refinement of somatotopic maps. Neuron 19:1201-1210.

Iwasato T, Datwani A, Wolf AM, Nishiyama H, Taguchi Y, Tonegawa S, Knopfel T, Erzurumlu RS, Itohara S (2000) Cortex-restricted disruption of NMDAR1 impairs neuronal patterns in the barrel cortex. Nature 406:726-731.

Jacquin MF, Zahm DS, Henderson TA, Golden JP, Johnson EM, Renehan WE, Klein BG (1993) Structure-function relationships in rat brainstem subnucleus interpolaris. X. Mechanisms underlying enlarged spared whisker projections after infraorbital nerve injury at birth. J Neurosci 13:2946-2964.

Jacquin MF, Rana JZ, Miller MW, Chiaia NL, Rhoades RW (1996) Development of trigeminal nucleus principalis in the rat: Effects of target removal at birth. Eur J Neurosci 8:1641-1657.

Killackey HP, Fleming K (1985) The role of the principal sensory nucleus in central trigeminal pattern formation. Brain Res 354:141-145.

Killackey HP, Jacquin MF, Rhoades RW (1990) The somatosensory system. In: Development of sensory systems in mammals (Coleman JR, ed). New York: Wiley.

Konishi Y, Ikeda K, Iwakura Y, Kawakami K (2006) Sixl and Six4 promote survival of sensory neurons during early trigeminal gangliogenesis. Brain Res 1116:93-102.

Lentz SI, Knudson CM, Korsmeyer SJ, Snider WD (1999) Neurotrophins support the development of diverse sensory axon morphologies. J Neurosci 19:1038-1048.

Li Y, Erzurumlu RS, Chen C, Jhaveri S, Tonegawa S (1994) Whisker-related neuronal patterns fail to develop in the trigeminal brainstem nuclei of NMDAR1 knockout mice. Cell 76:427-437.

Lu HC, Butts DA, Kaeser PS, She WC, Janz R, Crair MC (2006) Role of efficient neurotransmitter release in barrel map development. J Neurosci 26:2692-2703.

Lush ME, Ma L, Parada LF (2005) TrkB signaling regulates the developmental maturation of the somatosensory cortex. Int J Dev Neurosci 23:523-536.

Maier DL, Mani S, Donovan SL, Soppet D, Tessarollo L, McCasland JS, Meiri KF (1999) Disrupted cortical map and absence of cortical barrels in growth-associated protein (GAP)-43 knockout mice. Proc Natl Acad Sci USA 96:9397-9402. 

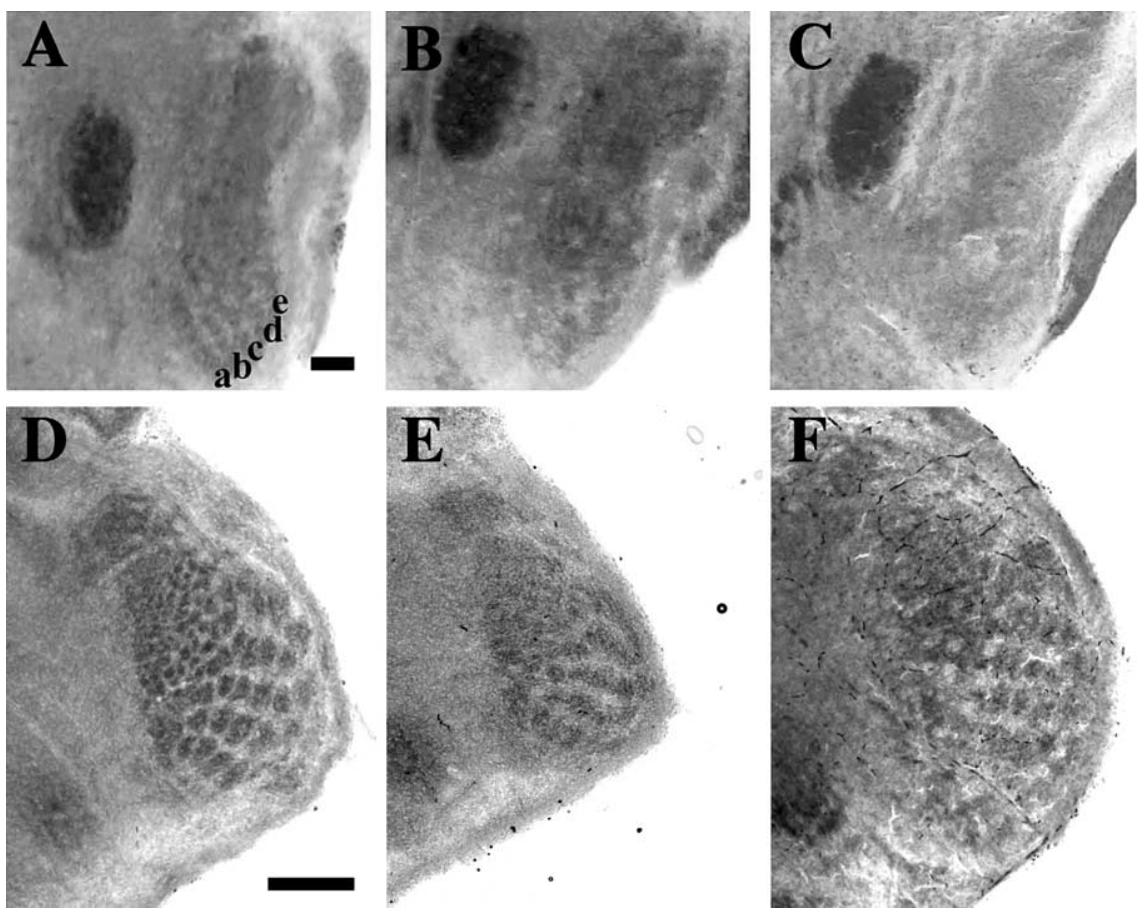

Figure 8. Cytochrome oxidase-stained coronal sections through the right $\operatorname{PrV}$ (top) and SpVi (bottom) of newborn mice from representative wild-type control $(\boldsymbol{A}, \boldsymbol{D}), D R G 11^{-/-}(\boldsymbol{B}, \boldsymbol{E})$, and Bax/DRG11 double $-/-(\boldsymbol{C}, \boldsymbol{F})$ cases. The darker elliptical structure to the left of the $\operatorname{Pr} V$ in $A-C$ is the $V$ motor nucleus. The five obliquely oriented rows of patches representing the five rows of whiskers on the face are indicated by the letters $\boldsymbol{a}-\boldsymbol{e}$ in $\boldsymbol{A}$. Note the absence of such patterns in $\boldsymbol{B}$ and $\boldsymbol{C}$. In contrast, all three genotypes show robust whisker-related patterning in SpVi (D-F). Scale bar: $\boldsymbol{A}-\boldsymbol{C}, 100 \mu \mathrm{m} ; \boldsymbol{D}-\boldsymbol{F}, 200 \mu \mathrm{m}$.

McEvilly RJ, Erkman L, Luo L, Sawchenko PE, Ryan AF, Rosenfeld MG (1996) Requirement for Brn-3.0 in differentiation and survival of sensory and motor neurons. Nature 384:574-577.

Oury F, Murakami Y, Renaud JS, Pasqualetti M, Charnay P, Ren SY, Rijli FM (2006) Hoxa2- and rhombomere-dependent development of the mouse facial somatosensory map. Science 313:1408-1413.

Qian Y, Shirasawa S, Chen CL, Cheng L, Ma Q (2002) Proper development of relay somatic sensory neurons and D2/D4 interneurons requires homeobox genes Rnx/Tlx-3 and Tlx-1. Genes Dev 16:1220-1233.

Rebelo S, Chen ZF, Anderson DJ, Lima D (2006) Involvement of DRG11 in the development of the primary afferent nociceptive system. Mol Cell Neurosci 33:236-246.

Shapiro LA, Ribak CE (2006) Newly born dentate granule neurons after pilocarpine-induced epilepsy have hilar basal dendrites with immature synapses. Epilepsy Res 69:53-66.

Shortland PJ, DeMaro JA, Shang F, Waite PME, Jacquin MF (1996) Peripheral and central predictors of whisker afferent morphology in the rat brainstem. J Comp Neurol 375:481-501.

Sikich L, Woolsey TA, Johnson EM (1986) Effect of a uniform partial denervation of the periphery on the peripheral and central vibrissal system in guinea pigs. J Neurosci 6:1227-1240.

Vanderhaeghen P, Lu Q, Prakash N, Frisen J, Walsh CA, Frostig RD, Flanagan JG (2000) A mapping label required for normal scale of body representation in the cortex. Nat Neurosci 3:358-365.

Wang CZ, Shi M, Yang LL, Yang RQ, Luo ZG, Jacquin MF, Chen ZF, Ding YQ (2007) Development of the mesencephalic trigeminal nucleus requires a paired homeodomain transcription factor, Drg11. Mol Cell Neurosci 35:368-376.

Watson RF, Abdel-Majid RM, Barnett MW, Willis BS, Katsnelson A, Gillingwater TH, McKnight GS, Kind PC, Neumann PE (2006) Involvement of protein kinase $\mathrm{A}$ in patterning of the mouse somatosensory cortex. J Neurosci 26:5393-5401.

Welker E, Armstrong-James M, Bronchti G, Ourednik W, Gheorghita-Baechler F, Dubois R, Guernsey DL, Van der Loos H, Neumann PE (1996) Science 271:1864-1867.

White FA, Keller-Peck CR, Knudson CM, Korsmeyer SJ, Snider WD (1998) Widespread elimination of naturally occurring neuronal death in Bax-deficient mice. J Neurosci 18:1428-1439.

Woolsey TA, Van der Loos H (1970) The structural organization of layer IV in the somatosensory region (SI) of the mouse cerebral cortex. Brain Res 17:205-242.

Wüllner U, Seyfried J, Groscurth P, Beinroth S, Winter S, Gleichmann M, Heneka M, Löschmann P, Schulz JB, Weller M, Klockgether T (1999) Glutathione depletion and neuronal cell death: the role of reactive oygen intermediates and mitochondrial function. Brain Res 826:53-62. 